\title{
ВЛИЯНИЕ РАЗЛИЧНЫХ КОНЦЕНТРАЦИЙ РОЗУВАСТАТИНА НА СЕКРЕЦИЮ ЛЕПТИНА И АДИПОНЕКТИНА АДИПОЦИТАМИ ЭПИКАРДИАЛЬНОЙ И ПОДКОЖНОЙ ЖИРОВОЙ ТКАНИ У ПАЦИЕНТОВ С ИШЕМИЧЕСКОЙ БОЛЕЗНЬЮ СЕРДЦА
}

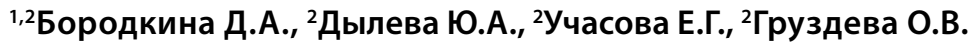

'ГАУЗ КО «Кемеровская областная клиническая больница» имени С.В. Беляева, Кемерово

${ }^{2}$ ФББНУ «Научно-исследовательский институт комплексных проблем сердечно-сосудистых заболеваний», Кемерово

ЦЕЛЬ: изучение влияние розувастатина на экспрессию мРНК гена лептина и адипонектина, а также их секрецию адипоцитами подкожной и эпикардиальной жировой ткани у больных ишемической болезнью сердца.

МАТЕРИАЛЫ И МЕТОДЫ: образЦЫ ЖИровой ткани поЛучены при проведении аортокоронарного шунтирования (АКШ) от 84 пациентов с ишемической болезнью сердца (ИБС). Эпикардиальная жировая ткань (ЭЖТ) забиралась из жировых отложений вокруг правых отделов сердца, подкожная (ПЖТ) 一 из подкожной клетчатки нижнего угла средостенной раны. Полученные образцы культивировали в течение 2 суток, с последующим забором супернатанта для определения содержания лептина и адипонектина, а также концентрации мPHК их генов. С целью изучения влияния розувастатина на функциональную активность адипоцитов ПЖТ и ЭЖТ проводили культивирование с ним клеточных культур в концентрациях 1 мкмоль/л и 5 мкмоль/л, с последующим определение содержания лептина и адипонектина в супернатанте и концентрации мРНК их генов. Содержание лептина и адипонектина в супернатанте определяли иммуноферментным методом с использованием тест-систем фирмы BioVendor (США) и eBioscience (Австрия). Экспрессию генов адипокинов оценивали с помощью количественной полимеразной цепной реакции (КПЦР) с использованием анализа экспрессии генов TaqManTM (Applied Biosystems, США) в системе ПЦР ViiA 7 (Applied Biosystems, США). Данные проанализированы с использованием пакета прикладных статистических программ Statistica 9.0.

РЕЗУЛЬТАТЫ: Установлено, что «метаболический» потенциал жировой ткани зависит от ее локализации. ЭЖТ характеризовалась более высокой экспрессией гена лептина по сравнению с ПЖТ. Так уровень мРНК гена лептина был в 2,1 раза выше в культуре ЭЖТ по сравнению с ПЖТ. Не смотря на, это существенной разницы в концентрации самого лептина в супернатанте исследуемых культур найдено не было. Так же для образцов ЭЖТ характерен более низкий уровень экспрессии гена адипонектина, на 20\% ниже, чем в адипоцитах ПЖТ. Более низкий уровень экспрессии сопровождался, и более низкой концентраций адипонектина. Добавления розувастатина, в концентрациях 1 и 5 мкмоль/л повышал содержание лептина и экспрессию его гена в большей степени в адипоцитах ЭЖТ в 2,3 раза и ПЖТ в 3,4 раза. В то время, как максимальное усиление экспрессии гена адипонектина и увеличение его концентрации в клеточных культурах регистрировалось, только при низких концентрация розувастатина, в 2,6 раза для ЭЖТ и 1,4 раза для ПжТ.

Введение в клеточные культуры адипоцитов ЭЖТ и ПЖТ розувастатина в концентрации 5 мкмоль/л, так же приводило к усиление экспрессии гена адипонектина и увеличению его концентрации по сравнению с контролем, но не так значимо, как под воздействием концентрации 1 мкмоль/л.

ВЫвОды: культивирование адипоцитов ЭЖТ И ПЖТ с розувастатином приводит к усилению выработки им протективного адипонектина, при чем эффект более выражен при использовании концентрации 1 мкмоль/л. Усиление выработки лептина происходит в обеих группах, не зависимо от концентрации. 